J. Lake Sci. (湖泊科学) , 2014, 26(6): 939-947

http://www. jlakes. org. E-mail : jlakes@niglas.ac.cn

(c) 2014 by Journal of Lake Sciences

\title{
基于浮游植物群落的安徽太平湖水环境生态评价”
}

\author{
王俊莉 ${ }^{1}$, 刘冬燕 $^{1,2 * *}$, 古滨河 ${ }^{3}$, 李东京 $^{1}$, 吴明姝 ${ }^{1}$ \\ $(1:$ 上海师范大学环境科学系, 上海 200234$)$ \\ ( 2 : 上海师范大学城市生态与环境研究中心,上海 200234) \\ (3: 暨南大学生态学系,广州 510063$)$
}

\begin{abstract}
摘 要: 安徽太平湖是国家重点保护湖泊,但其生态本底资料非常缺乏. 于 2012 、2013 年对太平湖浮游植物群落结构进 行了调查, 共鉴定出浮游植物 126 种, 隶属 7 门 93 属, 绿藻门种数最多, 共 40 属 68 种; 浮游植物丰度平均值为 $127.12 \times$ $10^{4} \mathrm{cells} / \mathrm{L}$, 蓝藻与绿藻相对丰度之和达 $61.5 \%$; 生物量平均值为 $0.74 \mathrm{mg} / \mathrm{L}$, 蓝藻和绿藻相对生物量之和达 $40.3 \%$; 太平 湖优势种种类多且优势度不高; $\alpha$-中污染和 $\beta$-中污染指示种分别为 9 和 28 种, 占总种数的 $7.1 \%$ 和 $22.2 \%$; 各采样点 Shannon-Wiener、Margalef 和 Pielou 均匀度指数的均值分别 2.48、2.35 和 0.71 . 利用各种浮游植物特征参数对太平湖水营 养水平的评价结果不太一致, 而各指标对太平湖水质污染状况的评价较为一致, 为 $\beta-\alpha$-中污染. 与以往的数据进行比较 发现, 太平湖浮游植物种类组成上未发生大的变化, 丰度及生物量呈现增加的趋势, 指示水体清洁的种类消失, 新增的浮 游植物种类超过 $50 \%$ 为中污带指示种, 但未见 P-多污带指示种类出现, 说明太平湖水生态环境质量有所下降, 但没有达 到恶化的程度.
\end{abstract}

关键词: 太平湖;浮游植物; 群落结构;优势种;多样性指数;生态评价

\section{Environmental assessment of Lake Taiping (Anhui Province) based on a phytoplankton community analysis}

\author{
WANG Junli $^{1}$, LIU Dongyan ${ }^{1,2}$, GU Binhe ${ }^{3}$, LI Dongjing ${ }^{1} \&$ WU Mingshu ${ }^{1}$ \\ (1:Department of Environmental Science, Shanghai Normal University, Shanghai 200234, P. R. China) \\ (2:Urban Ecology and Environment Research Centre, Shanghai Normal University, Shanghai 200234, P. R. China) \\ ( 3 :Department of Ecology, Jinan University, Guangzhou 510063, P. R. China)
}

Abstract: Lake Taiping is one of the national key protected lakes, but its ecological baseline information is lacking. A preliminary study was conducted on the phytoplankton community structure in Lake Taiping from September 2012 to March 2013. A total of 126 phytoplankton species belonging to 7 phyla, 93 genera were identified. The phytoplankton community was dominated by Chlorophyta, which is comprised of 40 genera and 68 species. The average phytoplankton cell density was $127.12 \times 10^{4}$ cells $/ \mathrm{L}$, in which Cyanophyta and Chlorophyta cells accounted for $61.5 \%$ of the total cell density. The average phytoplankton biomass is 0.74 $\mathrm{mg} / \mathrm{L}$ and $40.3 \%$ of them was Cyanophyta and Chlorophyta. There were a number of dominant planktonic species in Lake Taiping but none of them absolutely dominated. The number of indicator species of alpha and beta pollution is 9 and 28 , accounting for $7.1 \%$ and $22.2 \%$ of the total number of the species in the lake, respectively. The averages of Shannon-Wiener, Margalef index and Pielou evenness index at every sampling station were $2.48,2.35$ and 0.71 , respectively. The indexes of phytoplankton evaluation of Lake Taiping were not consistent, but all the indexes water quality indexes were relatively consistent, indicating that the experienced $\beta$ - $\alpha$-moderate pollution. Compared to previous reports, phytoplankton species composition in Lake Taiping did not change significantly. Cell density and biomass showed an increasing trend. Besides, the indicator species of clean-water have disappeared. More than $50 \%$ of the algal species were new to this lake and were indicator species of mesosaprobic zone, but indicator

* 国家自然科学基金项目 (31170441,31070419)、上海师范大学原创与前瞻性预研项目 (DYL201304)、上海地方院校 “十二五”内涵建设项目和国家水体污染控制与治理科技重大专项项目联合资助. 2013-12-27 收稿;2014-0306 收修改稿. 王俊莉 (1988 ), 女, 硕士研究生; E-mail : wangjunli. jsw@ 163.com.

** 通信作者;E-mail:liudy@ shnu. edu. cn. 
species of P-polysaprobic zone are not found. This suggests that the current water quality has declined, but is not deteriorated.

Keywords: Lake Taiping; phytoplankton; community structure; dominant species ; diversity index; ecological evaluation

保护水环境是当前全球的一大重要课题, 而通常用监测的方法达到保护的目的. 目前比较普遍的水环 境监测方法主要有两大类:一是运用理化指标进行水质的评价, 主要方法有模糊评价法、污染指数法、物元 分析法、单因子评价法、灰色评价法等; 二是生物监测, 而浮游植物又是生物监测中的重要指标. 浮游植物是 水域生态系统中主要的初级生产者之一 ${ }^{[1-3]}$, 在淡水生态系统的能量流动和物质循环传递中起着至关重要 的作用 ${ }^{[4]}$. 与其它评价方法相比, 生物监测有其独特的优点. 它能够全面地反映水环境的变化, 直接、全面地 反映水环境的污染情况, 通过汇集整个周期环境的变化情况来反映长期的水环境污染状况, 能将污染物予 以富集, 从而及早发现环境污染情况. 同时, 此方法也有其不足, 如不能确定污染物的种类和浓度, 灵敏性和 专一性不如理化监测, 耗时较长. 然而, 浮游植物的物种组成、数量特征及多样性等会随着水环境的变化而 改变, 通过检测浮游植物的群落特征可全面、及时掌握水环境质量的动态变化特征 ${ }^{[5-6]}$, 这正是理化监测所 无法替代的. 另外, 由于该研究为一项长期的研究, 故较大程度地避免了生物监测的不足之处. 当前, 利用浮 游植物评价各种水体水质状况与营养水平的研究已相当普遍 ${ }^{[-9]}$.

太平湖 $\left(30^{\circ} 0^{\prime} \sim 30^{\circ} 32^{\prime} \mathrm{N}, 117^{\circ} 28^{\prime} \sim 118^{\circ} 21^{\prime} \mathrm{E}\right.$ ) 位于安徽省黄山市黄山区境内, 始建于 1970 年. 东西长 $48 \mathrm{~km}$, 南北最宽处 $4 \mathrm{~km}$, 最窄处仅百米左右, 总面积 $88 \mathrm{~km}^{2}$, 是安徽省目前最大的人工湖, 也是全省唯一的 部属水库, 具有防洪、灌溉、发电、航运、水产养殖等多种功能, 也是庐山、九华山至黄山旅游热线上的一处诱 人的观光胜景. 而关于太平湖浮游植物的研究仅在 $1980 \mathrm{~s}$ 和 $1990 \mathrm{~s}$ 初进行过少量调查 ${ }^{[10-12]}, 2006$ 年一次简单 的调查之后再未见任何报道. 目前, 太平湖已被列入国家第二批生态环境保护专项, 本文正是基于 “太平湖 生态环境保护基线调查” 项目对太平湖的浮游植物群落进行调查分析, 利用多种指标对太平湖生态环境进 行评价, 同时, 与前人研究结果进行对比来分析太平湖的水生态环境演变趋势, 以期为太平湖的水生态环境 保护提供参考资料.

\section{1 材料与方法}

\section{1 采样点布设}

2012 年 9 月一 2013 年 3 月期间每隔 2 个月对太平湖进行一次采样, 时间分别为 2012 年 $9 、 11$ 月和 2013 年 $1 、 3$ 月. 共设 5 个采样点, 分别记为 $\mathrm{H} 1 、 \mathrm{H} 2 、 \mathrm{H} 3 、 \mathrm{H} 4 、 \mathrm{H} 5$ (图 1).

\section{2 样品的采集与处理}

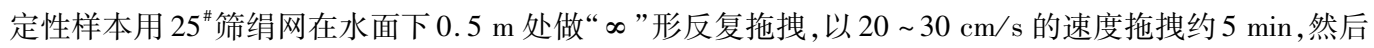
把网提起抖动滤水, 轻轻打开网头, 将液体倒人贴有标签的样品瓶中, 加人鲁哥试剂固定后参照文献 [13$16]$ 进行浮游植物种类鉴定.

定量样品在表、中、下 3 层各采水样 $3 \mathrm{~L}$, 现场加人鲁哥试剂并摇匀. 带回实验室沉淀、浓缩后镜检. 浮游 植物的观察计数用 $0.1 \mathrm{ml}$ 浮游植物计数框在 $10 \times 40$ 倍光学显微镜下进行. 计数时充分摇匀浓缩液, 然后立 即取 $0.1 \mathrm{ml}$ 样品放人计数框中全片计数. 每个样品计数 2 片, 取其平均值作为最终结果. 最后根据浓缩倍数 换算为每升水样中的细胞数 ( cells $/ \mathrm{L}$ ), 即浮游植物的丰度. 由于浮游植物的比重接近 1 , 故可以直接由浮游 植物的体积换算为生物量 (鲜重), 即生物量为浮游植物的丰度乘以各自的平均体积 ${ }^{[17]}$, 单位为 $\mathrm{mg} / \mathrm{L}$.

\section{3 水生态评价标准与方法}

1.3.1 浮游植物种类组成一般认为, 金藻、黄藻为贫营养型水体的优势种, 甲藻、隐藻和硅藻为中营养型水 体的优势种, 而绿藻、蓝藻为富营养型水体的优势种 ${ }^{[18]}$.

1.3 .2 浮游植物丰度与生物量 从浮游植物丰度指标来看, 小于 $30 \times 10^{4} \mathrm{cells} / \mathrm{L}$ 时, 水体为贫营养型; 在 $30 \times 10^{4} \sim 100 \times 10^{4} \mathrm{cells} / \mathrm{L}$ 之间时, 水体为中营养型; 大于 $100 \times 10^{4} \mathrm{cells} / \mathrm{L}$ 时, 水体为富营养型 ${ }^{[19]}$. 从浮游 植物生物量指标来看, 小于 $1 \mathrm{mg} / \mathrm{L}$ 时, 水体为贫营养型; 在 $1 \sim 5 \mathrm{mg} / \mathrm{L}$ 之间时, 水体为中营养型; 在 $5 \sim 10 \mathrm{mg} / \mathrm{L}$ 之间时, 水体为富营养型 ${ }^{[20]}$.

1.3 .3 优势种法 优势度法是用优势种的变化来评价水体污染状况的方法. 浮游植物优势种的种类在未受 


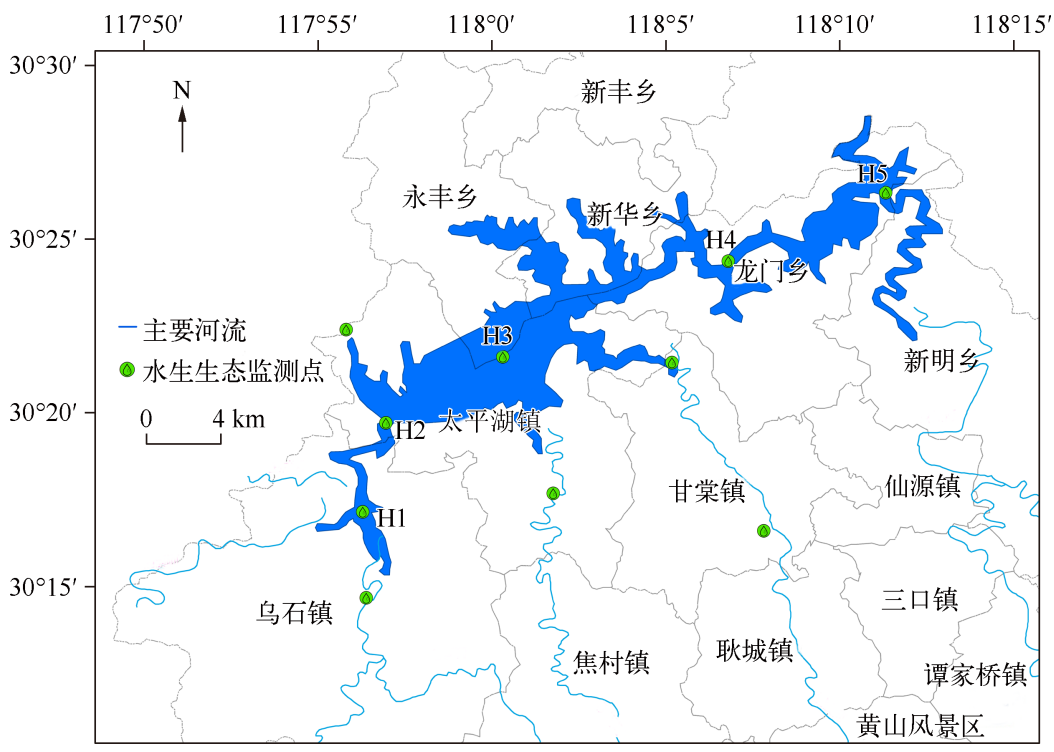

图 1 太平湖采样点分布

Fig. 1 Distribution of sampling sites of Lake Taiping

污染的水体中表现出多样性, 丰度也较高, 且以硅藻为主, 同时有少量蓝藻和绿藻; 受污染水体中的浮游植 物种类和丰度都明显减少, 群落组成也发生变化, 硅藻不再占优势, 各种丝状绿藻大量繁殖, 成为优势种. 污 染指示种类和丰度在一定程度上可直接反映水体污染程度和环境条件的改变 ${ }^{[6]}$.

本文采用 Mcnaughton 优势度指数 $Y$,其公式为:

$$
Y=\frac{N_{i}}{N} \times f_{i} \times 100 \%
$$

式中, $N_{i}$ 为第 $i$ 种物种的个体数, $N$ 为样品中全部物种的个体数, $f_{i}$ 为第 $i$ 种在所有采样点中出现的频率.

1.3.4 指示生物法 指示生物法是指根据对环境中有机污染或某种特定污染物质敏感的或有较高耐受性的 生物种类的存在或缺失,来指示其所在水体或河段污染状况的方法. 早在 1980 年, B. 福迪就对指示生物法 进行了较为详细的分析 ${ }^{[2]}$. 此方法是经典的生物学水质评价方法. 选作指示种的生物是生命期较长、比较固 定生活于某处的生物,可在较长时期内反映所在环境的综合影响.

1.3.5 Shannon-Wiener 多样性指数 Shannon-Wiener 多样性指数计算公式为:

$$
H^{\prime}=-\sum_{i=1}^{S}\left(\frac{N_{i}}{N} \ln \frac{N_{i}}{N}\right)
$$

式中, $S$ 为样点中物种的种类数. 根据评价标准, $H^{\prime}$ 值大于 3 时, 为轻度污染; $H^{\prime}$ 值为 $1 \sim 3$ 时, 为中度污染; $H^{\prime}$ 值为 $0 \sim 1$ 时, 为重度污染 ${ }^{[22]}$.

1.3.6 Margalef 多样性指数 Margalef 多样性指数计算公式为:

$$
d=\frac{S-1}{\ln N}
$$

根据评价标准, $d$ 值大于 3 时, 水体为轻度污染; $d$ 值为 $1 \sim 3$ 时, 为中度污染; $d$ 值为 $0 \sim 1$ 时, 为重度 污染 ${ }^{[22]}$.

1.3.7 Pielou 均匀度指数 Pielou 均匀度指数计算公式为:

$$
J=\frac{H^{\prime}}{\ln (S-1)}
$$


根据评价标准, $J$ 值为 $0.5 \sim 0.8$ 时, 为轻度污染; $J$ 值为 $0.3 \sim 0.5$ 时, 为中度污染; $J$ 值为 $0 \sim 0.3$ 时, 为 重度污染 ${ }^{[23]}$.

\section{2 结果与分析}

\section{1 浮游植物种类组成}

共鉴定出浮游植物 7 门 93 属 126 种 (包括变种). 其中, 绿藻门种数最多, 共 40 属 68 种, 占浮游植物总 种数的 $53.9 \%$; 其次为硅藻门和蓝藻门, 分别为 24 属 25 种和 16 属 17 种, 占总种数的 $19.8 \%$ 和 $13.5 \%$; 种 数最少的为隐藻门,有 2 属 3 种, 占总种数的 $2.38 \%$.

\section{2 浮游植物丰度和生物量}

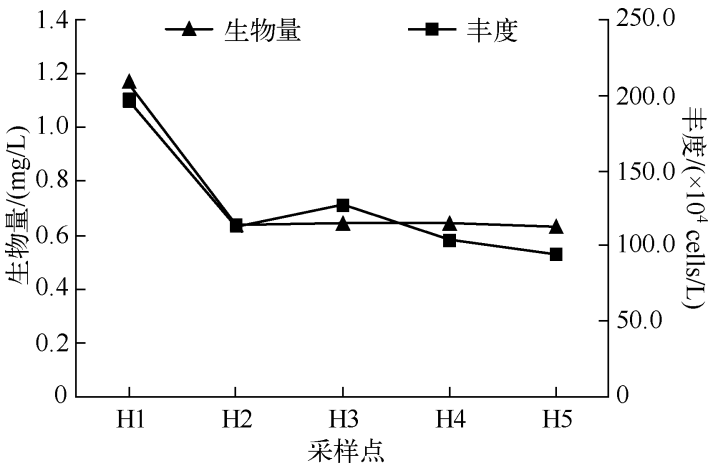

图 2 研究期间太平湖浮游植物丰度和生物量变化

Fig. 2 Variation of phytoplankton density and biomass in Lake Taiping during the research

调查区域 5 个采样点浮游植物丰度平均值 为 $127.12 \times 10^{4} \mathrm{cells} / \mathrm{L}$, 范围为 $94.54 \times 10^{4} \sim$ $196.29 \times 10^{4}$ cells $/ \mathrm{L}$; 生物量平均值为 $0.74 \mathrm{mg} / \mathrm{L}$, 范围为 $0.63 \sim 1.16 \mathrm{mg} / \mathrm{L}$ (图 2).

太平湖浮游植物丰度和生物量最低点均在 $\mathrm{H} 5$ 点, 最高点均在 $\mathrm{H} 1$ 点. 通过对各采样点浮游 植物丰度和生物量的对比发现, 虽然 $\mathrm{H} 3$ 点浮游 植物丰度高于 $\mathrm{H} 4$ 点, $\mathrm{H} 4$ 点生物量略高于 $\mathrm{H} 3$ (图 2 ), 这主要与不同种类的浮游植物个体大小相差 悬殊有关 ${ }^{[24]}$.

从整体变化来看, 上游人湖口 $\mathrm{H} 1$ 点浮游植 物丰度和生物量较高, 其余 4 个采样点之间无显 著差异. 出湖口 $\mathrm{H} 5$ 点浮游植物生物量较小 ( 图 $2)$, 表明太平湖具有一定的自净作用.

\section{3 优势种及其对水环境的指示性}

利用 Mcnaughton 优势度指数计算, 以优势度大于 $20 \%$ 定为优势种. 结果表明, 太平湖全年第 $1 、 2 、 3$ 优 势种分别为针杆藻、鱼腥藻和尖尾蓝隐藻, 优势度分别为 $0.091 、 0.074$ 和 0.049 (表 1). 其中, 针杆藻和尖尾 蓝隐藻为 $\beta$-中污带指示种, 鱼腥藻为 P-多污带指示种. 总体来说, 太平湖的优势种不明显, 虽然蓝藻门的颤 藻、鱼腥藻和水华束丝藻, 隐藻门的啮蚀隐藻和尖尾蓝隐藻, 硅藻门的针杆藻、脆杆藻、小环藻和直链藻, 绿 藻门的小球藻和四足十字藻的相对丰度较高,但它们的优势度较低.

表 1 研究期间太平湖浮游植物优势种

Tab. 1 Phytoplankton dominant species in Lake Taiping during the research

\begin{tabular}{|c|c|c|c|}
\hline 门类 & 中文名( 拉丁名) & 优势度 & 指示性 \\
\hline \multirow[t]{3}{*}{ 蓝藻门 } & 颤藻 (Oscillatoria sp. ) & 0.032 & $\beta$-中污染 \\
\hline & 鱼腥藻 ( Anabaena sp.) & 0.074 & P-多污染 \\
\hline & 水华束丝藻 (Aphanizomenon flos-aquae) & 0.036 & P-多污染 \\
\hline \multirow[t]{2}{*}{ 隐藻门 } & 啮蚀隐藻 (Cryptomonas erosa) & 0.034 & P-多污染 \\
\hline & 尖尾蓝隐藻 (Chroomonas acuta) & 0.049 & $\beta$-中污染 \\
\hline \multirow[t]{4}{*}{ 硅藻门 } & 针杆藻 (Synedra sp. ) & 0.091 & $\beta$-中污染 \\
\hline & 脆杆藻 (Fragilaria sp. ) & 0.026 & $\beta$-中污染 \\
\hline & 小环藻 (Cyclotella sp.) & 0.044 & $\beta$-中污染 \\
\hline & 直链藻 ( Melosira sp. ) & 0.043 & $\beta$-中污染 \\
\hline \multirow[t]{2}{*}{ 绿藻门 } & 小球藻 ( Chlorella sp. ) & 0.021 & P-多污染 \\
\hline & 四足十字藻 (Crucigenia tetrapedia) & 0.021 & $\beta$-中污染 \\
\hline
\end{tabular}




\section{4 指示种及其对水环境的指示性}

表 2 列举了太平湖中出现的浮游植物指示种类及其分布, 指示各种水质的典型浮游植物 ${ }^{[21]}$ 共 35 种, 占 全部种类的 $27.8 \%$. 其中,P-多污带指示种有 4 种, 占全部种类的 3. $2 \%$; $\alpha$-中污带指示种和 $\beta$-中污带指示种 分别有 9 种和 28 种,占总种数的 $7.1 \%$ 和 $22.2 \%$; $\mathrm{O}$-寡污带指示种共 11 种, 占总种数的 $8.7 \%$.

表 2 研究期间太平湖浮游植物指示种类及其分布 *

Tab. 2 Phytoplankton indicator species and distribution in Lake Taiping during the research

\begin{tabular}{|c|c|c|c|c|c|c|}
\hline \multirow{2}{*}{ 污染等级 } & \multirow{2}{*}{$\begin{array}{l}\text { 指示种 } \\
\text { 中文名(拉丁名) }\end{array}$} & \multicolumn{5}{|c|}{ 采样点 } \\
\hline & & H1 & $\mathrm{H} 2$ & $\mathrm{H} 3$ & $\mathrm{H} 4$ & H5 \\
\hline \multirow[t]{4}{*}{ P-多污带 } & 啮蚀隐藻 (Cryptomonas erosa) & $\checkmark$ & $\checkmark$ & $\checkmark$ & $\checkmark$ & $\checkmark$ \\
\hline & 小球藻 (Chlorella sp. ) & $\checkmark$ & $\checkmark$ & $\checkmark$ & $\checkmark$ & $\checkmark$ \\
\hline & 鱼腥藻 (Anabaena sp.) & $\checkmark$ & $\checkmark$ & $\checkmark$ & $\checkmark$ & $\checkmark$ \\
\hline & 水华束丝藻 (Aphanizomenon flos-aquae) & $\checkmark$ & $\checkmark$ & $\checkmark$ & $\checkmark$ & $\checkmark$ \\
\hline \multirow[t]{9}{*}{$\alpha$-中污带 } & 细小平裂藻 (Merismopedia minima) & $\checkmark$ & & $\checkmark$ & $\checkmark$ & $\checkmark$ \\
\hline & 啮蚀隐藻 ( Cryptomonas erosa) & $\checkmark$ & $\checkmark$ & $\checkmark$ & $\checkmark$ & $\checkmark$ \\
\hline & 席藻 ( Phormidium sp. ) & $\checkmark$ & $\checkmark$ & $\checkmark$ & & \\
\hline & 短缝藻( Eunotia sp. ) & & & $\checkmark$ & $\checkmark$ & $\checkmark$ \\
\hline & 桥弯藻 ( Cymbella sp. ) & $\checkmark$ & $\checkmark$ & $\checkmark$ & $\checkmark$ & $\checkmark$ \\
\hline & 四尾栅藻 (Scenedesmus quadricanda) & $\checkmark$ & $\checkmark$ & $\checkmark$ & $\checkmark$ & $\checkmark$ \\
\hline & 多芒藻 (Golenkinia sp. ) & $\checkmark$ & $\checkmark$ & $\checkmark$ & $\checkmark$ & $\checkmark$ \\
\hline & 小球藻 (Chlorella sp.) & $\checkmark$ & $\checkmark$ & $\checkmark$ & $\checkmark$ & $\checkmark$ \\
\hline & 拟新月藻( Closteropsis sp. ) & & & $\checkmark$ & $\checkmark$ & $\checkmark$ \\
\hline \multirow[t]{28}{*}{$\beta$-中污带 } & 细小平裂藻 (Merismopedia minima) & $\checkmark$ & & $\checkmark$ & & $\checkmark$ \\
\hline & 腔球藻 ( Coelosphaerium sp. ) & $\checkmark$ & $\checkmark$ & $\checkmark$ & $\checkmark$ & $\checkmark$ \\
\hline & 啮蚀隐藻 (Cryptomonas erosa) & $\checkmark$ & $\checkmark$ & $\checkmark$ & $\checkmark$ & $\checkmark$ \\
\hline & 飞燕角甲藻 ( Tiny ceratium) & & $\checkmark$ & $\checkmark$ & $\checkmark$ & $\checkmark$ \\
\hline & 卵形藻 (Cocconeis sp.) & $\checkmark$ & $\checkmark$ & & $\checkmark$ & $\checkmark$ \\
\hline & 星杆藻 (Asterionella sp. ) & $\checkmark$ & $\checkmark$ & $\checkmark$ & $\checkmark$ & $\checkmark$ \\
\hline & 小环藻 (Cyclotella sp. ) & $\checkmark$ & $\checkmark$ & $\checkmark$ & $\checkmark$ & $\checkmark$ \\
\hline & 直链藻 (Melosira sp.) & $\checkmark$ & $\checkmark$ & $\checkmark$ & $\checkmark$ & $\checkmark$ \\
\hline & 针杆藻 (Synedra sp. ) & $\checkmark$ & & $\checkmark$ & $\checkmark$ & $\checkmark$ \\
\hline & 脆杆藻 (Fragilaria sp. ) & $\checkmark$ & & $\checkmark$ & $\checkmark$ & $\checkmark$ \\
\hline & 短缝藻( Eunotia sp. ) & & & $\checkmark$ & $\checkmark$ & $\checkmark$ \\
\hline & 桥弯藻 ( Cymbella sp. ) & $\checkmark$ & $\checkmark$ & $\checkmark$ & $\checkmark$ & $\checkmark$ \\
\hline & 顶棘藻 ( Lagerheimiella chodat) & $\checkmark$ & $\checkmark$ & $\checkmark$ & $\checkmark$ & $\checkmark$ \\
\hline & 四尾栅藻 (Scenedesmus quadricanda) & $\checkmark$ & $\checkmark$ & $\checkmark$ & $\checkmark$ & $\checkmark$ \\
\hline & 多芒藻 ( Golenkinia radiata) & $\checkmark$ & $\checkmark$ & $\checkmark$ & $\checkmark$ & $\checkmark$ \\
\hline & 微芒藻 (Micractinium pusillum) & $\checkmark$ & $\checkmark$ & & $\checkmark$ & \\
\hline & 四足十字藻 (Crucigenia tetrapedia) & $\checkmark$ & & $\checkmark$ & $\checkmark$ & $\checkmark$ \\
\hline & 异棘四星藻 ( Tetrastrum heterocanthum) & & & & $\checkmark$ & \\
\hline & 鼓藻 (Cosmarium sp. ) & $\checkmark$ & $\checkmark$ & $\checkmark$ & $\checkmark$ & $\checkmark$ \\
\hline & 空星藻 ( Coelastrum sp. ) & $\checkmark$ & & $\checkmark$ & $\checkmark$ & $\checkmark$ \\
\hline & 实球藻 (Pandorina sp.) & $\checkmark$ & $\checkmark$ & $\checkmark$ & $\checkmark$ & $\checkmark$ \\
\hline & 空球藻 (Eudorina sp.) & $\checkmark$ & $\checkmark$ & $\checkmark$ & $\checkmark$ & \\
\hline & 拟新月 藻 ( Closteropsis sp. ) & & & $\checkmark$ & $\checkmark$ & $\checkmark$ \\
\hline & 二角盘星藻 ( Pediastrum duplex) & $\checkmark$ & $\checkmark$ & $\checkmark$ & $\checkmark$ & $\checkmark$ \\
\hline & 短棘盘星藻 ( Pediastrum boryanum) & $\checkmark$ & & & & \\
\hline & 双射盘星藻 (Peduastrum biradiatum) & & $\checkmark$ & $\checkmark$ & & \\
\hline & 肥壮蹄形藻 (Kirchneriella obesa) & $\checkmark$ & & $\checkmark$ & & \\
\hline & 月牙藻 (Selenastrum bibraianum) & & $\checkmark$ & $\checkmark$ & $\checkmark$ & $\checkmark$ \\
\hline \multirow[t]{11}{*}{ O-寡污带 } & 小环藻 ( Cyclotella sp. ) & $\checkmark$ & & $\checkmark$ & $\checkmark$ & $\checkmark$ \\
\hline & 脆杆藻 ( Fragilaria sp. ) & $\checkmark$ & $\checkmark$ & $\checkmark$ & $\checkmark$ & $\checkmark$ \\
\hline & 飞燕角甲藻 ( Tiny ceratium) & & $\checkmark$ & $\checkmark$ & $\checkmark$ & $\checkmark$ \\
\hline & 鼓藻 ( Cosmarium sp. ) & $\checkmark$ & $\checkmark$ & $\checkmark$ & $\checkmark$ & $\checkmark$ \\
\hline & 转板藻 (Mougeotia sp.) & $\checkmark$ & $\checkmark$ & $\checkmark$ & $\checkmark$ & $\checkmark$ \\
\hline & 实球藻 (Pandorina sp. ) & $\checkmark$ & $\checkmark$ & $\checkmark$ & $\checkmark$ & $\checkmark$ \\
\hline & 空球藻 (Eudorina sp. ) & $\checkmark$ & $\checkmark$ & $\checkmark$ & $\checkmark$ & \\
\hline & 短棘盘星藻 (Pediastrum boryanum) & $\checkmark$ & & & & \\
\hline & 双射盘星藻 (Peduastrum biradiatum) & & $\checkmark$ & $\checkmark$ & & \\
\hline & 鱼鳞藻 ( Mallomonas sp. ) & $\checkmark$ & $\checkmark$ & $\checkmark$ & $\checkmark$ & $\checkmark$ \\
\hline & 圆筒雉囊藻 (Dinobryon cylindricum) & $\checkmark$ & $\checkmark$ & $\checkmark$ & $\checkmark$ & $\checkmark$ \\
\hline
\end{tabular}

* “、”表示在该采样点中出现. 


\section{5 浮游植物多样性指数}

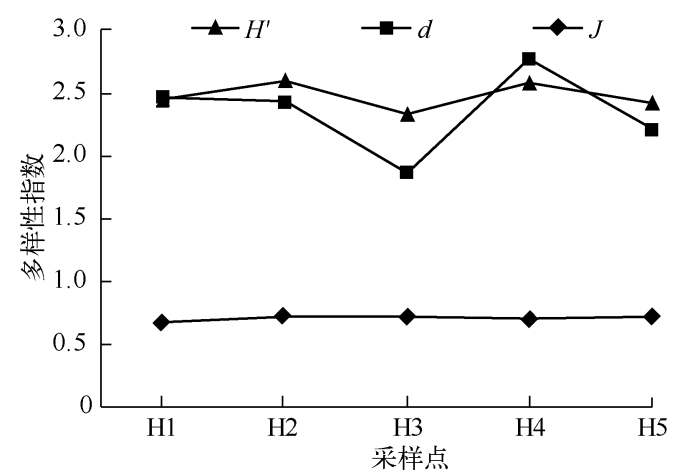

图 3 研究期间太平湖各采样点浮游 植物多样性指数变化

Fig. 3 Variation of phytoplankton diversity index in each study station of Lake Taiping during the research
生物多样性指数目前已被广泛用来描述浮游植 物群落构成情况及水体污染对生物所产生的影响, 值 得注意的是, 由于 Margalef 指数对群落多样性的判别 能力不高, 稀有种对该指数有较大影响, 所以结果可 能被错误理解, 因此 Margalef 指数在浮游植物群落结 构研究中要谨慎使用 ${ }^{[25]}$. 而 Shannon-Wiener 指数和 Margalef 指数分别代表对浮游植物群落物种数敏感 和不敏感的两类指数, 能较好的反映浮游植物群落多 样性 ${ }^{[26]}$. 鉴于此, 本文运用 Shannon-Wiener 指数、 Margalef 指数和 Pielou 均匀度指数相结合对太平湖 浮游植物群落进行分析.

研究期间,太平湖 5 个采样点的 $H^{\prime} 、 d$ 和 $J$ 值的 平均值分别为 $2.48 、 2.35$ 和 0.71 . 从采样点水平来 看, 由于湖心 $\mathrm{H} 3$ 点处于旅游码头水质较差, $H^{\prime}$ 与 $d$ 值明显低于其它 4 个采样点, 整体变化呈“ $V$ 字型. 而 Pielou 均匀度指数 $J$ 值在 5 个采样点基本相同, 较为 稳定 (图 3).

\section{3 讨论}

\section{1 太平湖水生态评价}

浮游植物对外界环境反映敏感, 浮游植物群落的结构随水的化学组成而改变, 因此可用来分析水环境 质量 ${ }^{[27]}$.

3.1 .1 浮游植物种类组成 从浮游植物种类组成上看, 太平湖各采样点 4 次采样平均种类数均为绿藻 + 蓝 藻 $>$ 硅藻 + 甲藻 + 隐藻 $>$ 金藻 + 黄藻, 但绿藻 + 蓝藻与硅藻 + 甲藻 + 隐藻相差不大. 一般认为, 金藻、黄藻 为贫营养型水体的优势种, 甲藻、隐藻和硅藻为中营养型水体的优势种, 而蓝藻、绿藻为富营养型水体的优 势种 ${ }^{[18]}$. 因此, 从种类组成来看, 太平湖水体为中一富营养水体.

3.1 .2 浮游植物丰度与生物量 从浮游植物丰度和生物量来看, 各采样点生物量平均值为 $0.74 \mathrm{mg} / \mathrm{L}$, 指示 水体为贫营养型 $(<1 \mathrm{mg} / \mathrm{L})$; 浮游植物丰度平均值为 $127.12 \times 10^{4}$ cells $/ \mathrm{L}$, 指示水体为富营养型 $(>100 \times$ $10^{4} \mathrm{cells} / \mathrm{L}$ ). 由此可见,利用浮游植物的丰度和生物量对水体营养状态所作出的评价结果不同.

研究表明, 代表富营养种类的蓝藻与绿藻相对丰度之和 $(44.5 \%+17.0 \%=61.5 \%)$ 与代表中营养种类 的硅藻、隐藻和甲藻相对丰度之和 $(26.0 \%+8.7 \%+0.4 \%=35.1 \%)$ 相差近 1 倍, 因此, 从浮游植物各门类 相对丰度来看, 太平湖属于富营养水体; 代表富营养种类的蓝藻与绿藻的相对生物量之和 $(28.8 \%+11.5 \%=$ $40.3 \%)$ 与代表中营养种类的硅藻、隐藻与甲藻相对生物量之和 $(24.4 \%+13.4 \%+3.1 \%=40.9 \%)$ 基本一 致, 从浮游植物各门类相对生物量来看, 太平湖属于贫一中营养水体.

一般认为, 由于不同种类浮游植物大小不同, 浮游植物的丰度特征不能客观地反映营养状态, 相比而 言, 生物量更能可靠地反映水质的营养状态 ${ }^{[28]}$. 因此, 浮游植物生物量评价结果显示, 太平湖属于贫一中营 养水体.

3.1 .3 浮游植物优势种 利用优势种对太平湖各采样点进行水质评价 (表 3 ), 结果表明, 4 次采样共检出优 势种 11 种, 其中, $\beta$-中污带指示种占优势种总量的 $54.5 \%$; 各采样点的优势种也均以 $\beta$-中污带指示种为主, 种类多且优势度不高, 说明水体质量处于较好水平, 整体来看太平湖为 $\beta$-中污染状态 ${ }^{[21]}$.

3.1 .4 浮游植物指示生物种类各采样点 $\alpha$-中污带指示种和 $\beta$-中污带指示种最多 (表 2 ). 其中, 湖心 $\mathrm{H} 3$ 点的 P-多污带指示种和中污带指示种在 5 个采样点中均最多. 另外, 由于湖心 $\mathrm{H} 3$ 点是太平湖旅游 接待中心, 较其它采样点人为污染相对严重, 多因素共同指示此点水质状况相对较差. 其余 4 个采样点 
的指示种也主要以中污带指示种为主. Kolkwitz 等认为当某污染水体中某种污染指示种类的种数占优 势时, 研究水域即可评价为该污染型水体 ${ }^{[29]}$. 由于太平湖的 $\beta-\alpha$-中污带指示种最多, 因此水环境质量 为 $\beta-\alpha$-中污染.

表 3 研究期间太平湖各样点浮游植物优势种及其对水质的指示

Tab. 3 Phytoplankton dominant species as indicators for water quality in Lake Taiping during the research

\begin{tabular}{|c|c|c|c|}
\hline \multirow{2}{*}{ 采样点 } & \multicolumn{3}{|c|}{ 优势种 } \\
\hline & $\mathrm{O}$-寡污带指示种 & $\beta$-中污带指示种 & P-多污带指示种 \\
\hline H1 & 直链藻、四足十字藻 & 颤藻、尖尾蓝隐藻、针杆藻、小环藻、脆杆藻 & 水华束丝藻、啮蚀隐藻 \\
\hline $\mathrm{H} 2$ & 直链藻 & 尖尾蓝隐藻、针杆藻、脆杆藻 & 水华束丝藻、啮蚀隐藻 \\
\hline $\mathrm{H} 3$ & 直链藻、四足十字藻 & 颤藻、鱼腥藻、针杆藻、小环藻、脆杆藻 & 水华束丝藻、啮蚀隐藻 \\
\hline $\mathrm{H} 4$ & - & 颤藻、针杆藻、小环藻、脆杆藻 & 水华束丝藻、啮蚀隐藻、小球藻 \\
\hline H5 & 四足十字藻 & 颤藻、鱼腥藻、尖尾蓝隐藻、针杆藻、小环藻、脆杆藻 & 水华束丝藻、啮蚀隐藻 \\
\hline
\end{tabular}

3.1 .5 浮游植物多样性指数 Margalef 多样性指数反映的是浮游植物种类数与环境之间的关系, 由于 Margalef 多样性指数只考虑了种类数和个体数量的关系, 而忽略了个体数量在各种间分配的状况, 因此,在评价 水质时, 最好采用 Shannon-Wiener 多样性指数 $\left(H^{\prime}\right)$ 、Peilou 多样性指数 $(J)$ 与 Margalef 多样性指数 $(d)$ 结合 对太平湖中浮游植物的多样性进行验证. 太平湖各采样点的 Shannon-Wiener 多样性指数、Margalef 多样性指 数和 Pielou 均匀度指数差别均不明显. 从湖心 $\mathrm{H} 3$ 点向边缘, 多样性指数大体呈现增长的趋势 (图 3). 有报 道指出, 水体具有一定的物理、化学及生物自净能力, 越到湖心净化程度越高 ${ }^{[30]}$. 然而, 由于湖心 $\mathrm{H} 3$ 点周围 为码头, 游客较多, 受人为影响较大, 水质略差,多样性较低,这与评价结果较为一致, $\mathrm{H} 3$ 点的 $d$ 值与 $H^{\prime}$ 值均 最低. 各样点 $d$ 和 $H^{\prime}$ 值均在 $1 \sim 3$ 之间, $J$ 值在 $0.5 \sim 0.8$ 之间 (图 3), 根据各多样性指数的评价标准, 3 种多 样性指数共同指示太平湖水质为轻一中度污染.

\section{2 太平湖水环境质量变化趋势}

太平湖浮游植物种类组成的历年数据 (图 4)显示, 1985-1986 年和 1992-1993 年都鉴定出浮游植物 8 门, 分别有 175 种 和 112 种 ${ }^{[10-12]}, 2006$ 年的调查显示, 太平湖 共有浮游植物 6 门 30 种 (安徽省黄山市黄 山区环保局提供), 本次调查 (2012 年) 鉴 定到 7 门 126 种. 本次调查结果与历年结 果相比, 浮游植物门类有所减少, 种类数整 体上没有大的变化. 但与 2006 年相比, 2012 年太平湖浮游植物种类增多, 其中, 绿 藻门、硅藻门和蓝藻门种类数有较大幅度 的增长, 反映出水体中的营养物比 2006 年 同期丰富.

对比前后 4 次对太平湖调查的结果，

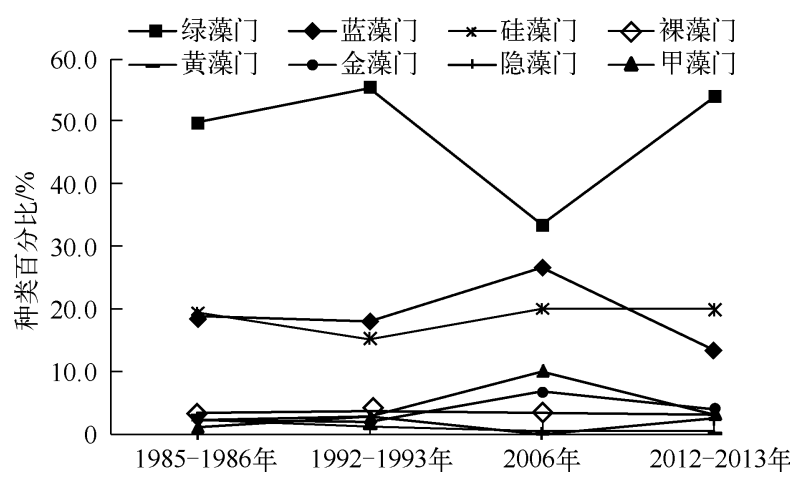

图 4 太平湖历年浮游植物的种类组成百分比的变化

Fig. 4 Percentage changes of phytoplankton species number in Lake Taiping over the years 在浮游植物种类组成上, 多年来未发生大的变化, 均以绿藻门、蓝藻门、硅藻门居多, 其中绿藻占主要地位 (图 4). 另外, 黄藻门及绿藻门中的团藻等指示水体清洁的种类和蓝纤维藻 (Dactylococcopsis sp.) 已消失, 而 具有污水指示意义 ${ }^{[21]}$ 的藻类有所增加, 在新增的浮游植物中, 超过 $50 \%$ 为中污带指示种, 未见 P-多污带指 示种 (表 4), 这一现象在一定程度上反映出水质有所下降,但没有达到恶化程度.

太平湖历年浮游植物丰度及生物量的变化显示, 虽然 2012 年较 1992-1993 年的浮游植物丰度略有减 少, 但整体趋势是增加的. 本次调查的浮游植物丰度较 $1992-1993$ 年减少了 $9.0 \%$, 生物量却增加了 $62.0 \%$, 二者相差较大 (图 5), 这表明大体积的浮游植物有较大程度地增加. 
表 4 本研究与 2006 年调查相比新增的指示生物种类

Tab. 4 New phytoplankton indicator species based on the comparison of this study and the year of 2006

\begin{tabular}{|c|c|}
\hline 污染等级 & 新增指示藻类 \\
\hline$\alpha$-中污带 & 席藻、短缝藻、桥弯藻、多芒藻、拟新月藻 ～～～～～～ \\
\hline$\beta$-中污带 & $\begin{array}{l}\text { 卵形藻、星杆藻、短缝藻、桥弯藻、顶棘藻、多芒藻、微芒藻、异棘四星藻、鼓藻、空星藻、实球藻、拟新 } \\
\text { 月藻、二角盘星藻、短棘盘星藻、双射盘星藻、肥壮蹄形藻 }\end{array}$ \\
\hline O-寡污带 & 脆杆藻、鼓藻、转板藻、实球藻、短棘盘星藻、双射盘星藻、圆筒雉囊藻 \\
\hline
\end{tabular}

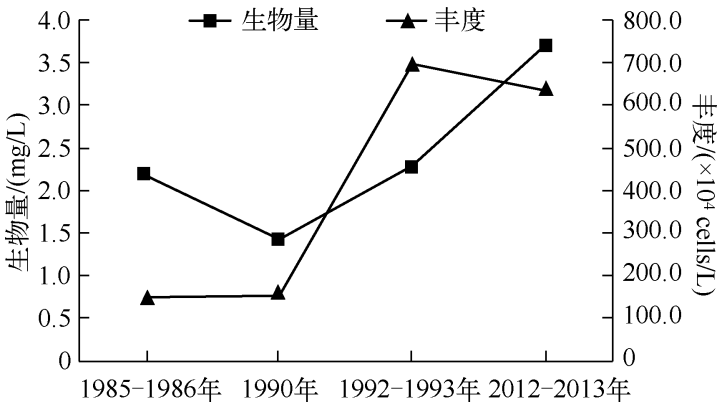

图 5 太平湖历年浮游植物丰度及生物量的变化

Fig. 5 Changes of phytoplankton cell density and biomass in Lake Taiping over the years

\section{4 结论}

1) 共鉴定出太平湖浮游植物 7 门 93 属 126 种, 其中绿藻门种类最多, 共 40 属 68 种, 占总种 数的 $53.9 \%$; 其次是硅藻门和蓝藻门, 分别有 24 属 25 种和 16 属 17 种, 占总种数的 $19.8 \%$ 和 $13.5 \%$, 其余门类种数较少, 最少的为隐藻门 ( 2 属 3 种).

2) 太平湖浮游植物丰度平均值为 $127.12 \times$ $10^{4}$ cells $/ \mathrm{L}$, 范围为 $94.54 \times 10^{4} \sim 196.29 \times$ $10^{4}$ cells $/ \mathrm{L}$; 生物量平均值为 $0.74 \mathrm{mg} / \mathrm{L}$, 范围为 $0.63 \sim 1.16 \mathrm{mg} / \mathrm{L}$. 浮游植物丰度与生物量均表 现为上游人水口高, 下游出水口较低.

3 ) 太平湖的优势种不明显, 相对数量较多的是蓝藻门的颤藻、鱼腥藻、水华束丝藻, 隐藻门的啮蚀隐藻、 尖尾蓝隐藻, 硅藻门的针杆藻、脆杆藻、小环藻、直链藻, 绿藻门的小球藻和四足十字藻. 其中 $54.5 \%$ 的优势 种指示水体为 $\beta$-中污染; 浮游植物指示种类分析表明, 太平湖水体的水质状况为 $\beta-\alpha$-中污染; 浮游植物多样 性指数在 5 个采样点差别不大, Shannon-Wiener 多样性指数 $H^{\prime}$ 、Margalef 多样性指数 $d$ 、Pielou 均匀度指数 $J$ 的均值分别为 $2.48 、 2.35$ 和 0.71 , 共同显示太平湖多样性、稳定性和均匀度较好, 且有由湖心 $\mathrm{H} 3$ 向上、下游 逐渐减小的趋势.

4 ）与历年调查结果相比, 太平湖浮游植物种类未发生大的变化, 均为绿藻门占主要地位, 但是大体积的 浮游植物较大幅度地增加. 在水质方面, 黄藻门及绿藻门中的团藻等指示清洁水体的种类已消失, 而超过 $50 \%$ 的新增浮游植物指示水体为中污染, 指示水质有下降的趋势, 但没有达到恶化程度.

如上所述,2012 年 9 月至 2013 年 3 月共 4 次对太平湖的监测结果表明, 太平湖目前水质状况尚好, 处 于轻一中度污染状态, 但与历年数据相比, 水质仍有下降的趋势. 从各样点来看, 湖心 $\mathrm{H} 3$ 水质较其它采样点 明显较差, 为使各采样点差距减小并处于较好水质水平, 应尽量控制湖区内的游客数量, 防止污水直接进人 湖区, 合理开发旅游项目, 继续贯彻实施当前禁捕的规定, 有效减少人为污染. 同时, 应对太平湖水质进行长 期连续的监测,并建立相应的生态保护方案, 避免太平湖生态系统受到破坏.

\section{5 参考文献}

[ 1 ] 张 民,于 洋,钱善勤等. 云贵高原湖泊夏季浮游植物组成及多样性. 湖泊科学, 2010,22(6):829-836.

[ 2 ] 庄军莲,许铭本, 张荣灿等. 广西防城港湾周年浮游植物生态特征. 应用生态学报,2011,22(5):1309-1315.

[ 3 ] Salmaso N. Long-term phytoplankton community changes in a deep subalpine lake: Responses to nutrient availability and climatic fluctuations. Freshwater Biology, 2010, 55 :825-846.

[ 4 ] 张 婷, 宋立荣. 铜绿微囊藻 (Microcystis aeruginosa) 与三种丝状蓝藻间的相互作用. 湖泊科学, 2006, 18 (2) : $150-156$.

[ 5] 吴 波. 上海苏州河、黄浦江浮游植物群落结构及其对环境指示作用的研究 [学位论文]. 上海: 上海师范大 学, 2006 . 
[6] 胡方凡. 袁河浮游藻类群落结构及其与环境因子的关系 [学位论文]. 南昌: 南昌大学, 2011 .

[7] 申恒伦, 蔡庆华, 邵美玲等. 三峡水库香溪河流域梯级水库浮游植物群落结构特征. 湖泊科学, 2012,24 (2): 197-205.

[8] 薛 建,刘华萍. 用浮游植物评价淮南市窑河水域的水质状况. 四川环境,2004,23(5):65-67.

[ 9 ] 王 瑜, 刘录三, 舒俭民等. 白洋淀浮游植物群落结构与水质评价. 湖泊科学, 2011,23(4):575-580.

[10］况琪军,夏宜琤. 太平湖水库的藻类与营养型评价. 应用生态学报,1992,3(2):165-198.

[11］裴满意. 太平湖浮游生物及鲢鳙鱼产潜力. 水产学杂志, 1995,8(2):41-45.

[12] 况琪军,夏宜琤. 太平湖水库藻类演替与营养侦别研究. 湖泊科学, 1995, 7 (3) :235-239.

[13］韩茂森,束蕴芳. 中国淡水生物图谱. 北京: 海洋出版社, 1995:2-134.

[14] 胡鸿钧,魏印心. 中国淡水藻类——系统、分类及生态. 北京:科学出版社,2006:1-915.

[15] 齐雨藻, 李家英. 中国淡水藻志, 第十卷, 硅藻门, 羽纹纲. 北京:科学出版社,2004:1-104.

[16] 齐雨藻. 中国淡水藻志, 第四卷, 硅藻门,中心纲. 北京:科学出版社, 1995:1-161.

[17] Lagus A, Suomela J, Helminen H et al. Impacts of nutrient enrichment and sediment on phytoplankton community structure in the northern Baltic Sea. Hydrobiologia, 2007,579(1):351-368.

[18] 刘建康. 高级水生生物学. 北京:科学出版社,2000:1-323.

[19] 王明翠, 刘雪芹, 张建辉. 湖泊富营养化评价方法及分级标准. 中国环境监测, 2002,18(5):47-49.

[20］沈暳芬,章宗涉等. 微型生物监测新技术. 北京:中国建筑出版社, 1990:126-136.

[21] B. 福迪. 藻类学. 上海: 上海科学技术出版社, $1980: 422-428$.

[22] Wilhm JL. Use of biomass units in shannons formula. Ecology, 1968, 49(1):153-155.

[23] 沈暳芬,章宗涉,龚循矩等. 微型生物监测新技术. 北京: 中国建筑工业出版社, 1990:136.

[24] 胡方凡, 王毛兰, 周文斌. 袁河浮游藻类群落结构与水质评价. 水生态学杂志, 2011,32(1):27-33.

[25] 孙 军, 刘东艳. 多样性指数在海洋浮游植物研究中的应用. 海洋学报, 2004,26(1):62-75.

[26] 雷安平,施之新, 魏印心. 武汉东湖浮游藻类物种多样性的研究. 水生生物学报, 2003,27(2):179-184.

[27] 刘冬燕,赵建夫,张亚雷等. 绥宁河生物修复中浮游植物的生态特征研究. 应用生态学报,2005,16(4):703-707.

[28] 赵先富, 于 军, 葛建华等. 青岛棘洪滩水库浮游藻类状况及水质评价. 水生生物学报,2005,29(6):639-644.

[29] Kolkwitz R, Marrson M. Okologie der tierischen saprobien. Internationale Revue der gesamten Hydrobiologie und Hydrographie, 1909, 2(1/2):126-152.

[30] 武发思, 鄢 金, 蔡泽平等. 大、小苏干湖浮游藻类的群落组成特点研究. 水生生物学报, 2009, 33(2):264-269. 